\title{
Hubungan Pengetahuan, Sikap Ibu dan Dukungan Keluarga dengan Kurangnya Minat Ibu Bersalin di Fasilitas Kesehatan Wilayah Kerja Puskesmas Sukarami Kecamatan Sungai Rotan Kabupaten Muara Enim
}

\author{
Delli Aridasari ${ }^{1 *}$, Erma Puspita Sari ${ }^{2}$, Siti Aisyah Hamid ${ }^{3}$, Eka Rahmawati ${ }^{4}$ \\ ${ }^{1}$ Mahasiswi Program Studi Kebidanan Universitas Kader Bangsa Palembang \\ 2,3,4 Universitas Kader Bangsa, Jln HM Ryacudu No 887 Ulu Palembang Sumatera Selatan \\ *Correspondence e-mail: ermapuspitasari88@gmail.com
}

\begin{abstract}
Abstrak. Berdasarkan Permenkes No.97 Tahun 2014 Pasal 14,yaitu ayat satu menyatakan persalinan harus dilakukan di fasilitas kesehatan. berdasarkan data dari Kementrian RI 2019, Dinkes Sumsel 2019, Riskesdes 2019, Dinkes Sumsel 2019, Dinkes Kabupaten Muara Enim dan Puskesmas Sukarami masih ada persalinan yang di lakukan bukan di fasilitas kesehatan. Persalinan yang di lakukan bukan di fasilitas kesehatan akan adanya komplikasi persalinan,lambat mendapatkan pelayanan bila terjadi komplikasi dan meningkatkan risiko infeksi. Tujuan dari penelitian ini adalah Untuk mengetahui hubungan pengetahuan,sikap ibu dan dukungan keluarga dengan kurangnya minat ibu bersalin di fasilitas kesehatan. Penelitian ini mengunakan survei analitik dengan metode kuantitatif dengan desain penelitian cross sectional. Penelitian ini dilakukan pada bulan Agustus 2021 di Puskesmas Sukarami Kecamatan Sungai Rotan Kabupaten Muara Enim Sumatera Selatan.Populasi penelitian ini yaitu semua ibu bersalin di wilayah kerja Puskesmas Sukarami pada tahun 2021 yang berjumlah 301 orang.Sampel yang digunakan berjumlah 75 dari populasi yang diambil dengan mengunakan rumus penentuan sampel.Analisa data mengunakan analisa univariat (proporsi) dan Analisa bivariat (uji chi square). Hasil Analisa menunjukan bahwa pengetahuan ( $p$ value $=0,022)$, Sikap Ibu $(p$ value $=$ 0,032) dan Dukungan Keluarga $(p$ value $=0,018)$ memiliki hubungan signifikan dengan ibu bersalin di fasilitas kesehatan. Kesimpulan dari penelitian ini adalah terdapat pengaruh antara pengetahuan, sikap ibu dan dukungan keluaga dengan kurangnya minat ibu bersalin di fasilitas kesehatan
\end{abstract}

Kata kunci: Dukungan Keluarga; Fasilitas Kesehatan; Pengetahuan; Sikap Ibu

\begin{abstract}
Based on Permenkes No.97 of 2014 Article 14, i.e. paragraph one states that childbirth must be carried out in a health facility. Based on data from the 2019 RI Ministry of Health, South Sumatra Health Office 2019, Riskesdes 2019, South Sumatra Health Office 2019, Muara Enim District Health Office and Sukarami Health Center there are still deliveries that are not carried out in health facilities. Deliveries that are not carried out at a health facility will lead to complications of childbirth, delay in getting services if complications occur and increase the risk of infection. The purpose of this study was to determine the relationship between knowledge, mother's attitude and family support with the lack of interest of mothers giving birth in health facilities. This study uses an analytical survey with quantitative methods with a cross sectional research design. This research was conducted in August 2021 at the Sukarami Health Center, Sungai Rotan District, Muara Enim Regency, South Sumatra. The population of this study were all mothers giving birth in the work area of the Sukarami Health Center in 2021, amounting to 301 people. The sample used amounted to 75 of the population taken by using the formula for determining the sample. Data analysis used univariate analysis (proportion) and bivariate analysis (chi square test). The results of the analysis showed that knowledge ( $p$ value $=0.022)$, Mother's Attitude ( $p$ value $=0.032)$ and Family Support ( $p$ value $=0.018)$ had a significant relationship with mothers giving birth in health facilities. The conclusion of this study is that there is an influence between knowledge, mother's attitude and family support with the lack of interest of mothers giving birth in health facilities.
\end{abstract}

Keywords : Family Support; Health Facilities; Knowledge; Mother's Attitude

\section{PENDAHULUAN}

Berdasarkan Permenkes No.97 Tahun 2014 Pasal 14 ayat satu menyatakan Persalinan harus dilakukan di fasilitas pelayanan kesehatan. Sedangkan ayat dua Persalinan sebagaimana dimaksud pada ayat (1) diberikan kepada ibu bersalin dalam bentuk 5 (lima) aspek dasar meliputi membuat keputusan klinik, asuhan sayang ibu dan sayang bayi, pencegahan infeksi, pencatatan (rekam medis) asuhan persalinandan rujukan pada kasus komplikasi ibu dan bayi baru lahir. Persalinan sebagaimana dimaksud pada ayat (2) dilakukan sesuai dengan standar Asuhan Persalinan Normal (APN).Pelayanan kesehatan selama masa kehamilan, persalinan dan nifas sangat penting bagi keberlangsungan hidup ibu dan bayi, termasuk dalam upaya menurunkan angka kematian ibu dan bayi baru lahir. Pelayanan kesehatan ibu menjadi prioritas utama pembangunan kesehatan nasional maupun global.Pemerintah Republik Indonesia telah mentargetkan peningkatan cakupan pelayanan kesehatan ibu sebagaimana tercantum dalam Rencana Pembangunan Jangka Menengah Nasional (RPJMN) 2015-2019 (SDKI, 2017).

Berdasarkan hasil riset kesehatan dasar 2018, didapatkan $16 \%$ persalinan pada perempuan umur 1549 tahun dilakukan tidak pada fasilitas kesehatan (Kemenkes RI, 2018) apabila dibandingkan dengan data SDKI tahun 2017 persalinan yang dilakukan tidak pada 
Delli Aridasari et al., Hubungan Pengetahuan, Sikap Ibu dan Dukungan Keluarga dengan Kurangnya Minat Ibu Bersalin di Fasilitas Kesehatan Wilayah Kerja Puskesmas Sukarami Kecamatan Sungai Rotan Kabupaten Muara Enim

fasilitas kesehatan sebesar 21\% (SDKI, 2017). Salah satu upaya pemerintah dalam menjawab tantangan tersebut dengan cara menetapkan indikator bahwa persalinan wajib ditolong tenaga kesehatan di fasilitas pelayanan kesehatan dalam PMK no. 4 tahun 2019 dan Rencna strategis 2015-2019 (Kementrian Kesehatan RI, 2019). Salah satu sasaran KPM PKH dalam bidang kesehatan adalah Ibu hamil memiliki kewajiban bersalin di fasilitas kesehatan (Kementerian RI, 2019)

Hasil SDKI 2017 memperlihatkan bahwa 96\% wanita bersalin di fasilitas pelayanan kesehatan, di antaranya $44 \%$ di fasilitas pelayanan kesehatan tingkat pertama yang meliputi puskesmas dan jaringannya, klinik serta praktik tenaga kesehatan, dan 52\% di fasilitas pelayanan rujukan tingkat lanjutan yakni rumah sakit, wanita melahirkan di tempat praktik tenaga kesehatan, dokter umum, dokter kandungan, bidan atau perawat terlatih (SDKI, 2017).

Sedangkan tahun 2019 terdapat 90,95\% persalinan yang ditolong tenaga kesehatan. Sementara ibu hamil yang menjalani persalinan dengan ditolong oleh tenaga kesehatan di fasilitas pelayanan kesehatan sebesar $88,75 \%$. Dengan demikian masih terdapat sekitar 2,2\% persalinan yang ditolong tenaga kesehatan namun tidak dilakukan di fasilitas pelayanan kesehatan. Hasil Riskesdas 2018 memperlihatkan tempat persalinan paling banyak digunakan yaitu rumah sakit (baik pemerintah maupun swasta) dan praktek tenaga kesehatan (nakes). Namun penggunaan rumah masih cukup tinggi sebesar 16,7\%, yang menempati urutan ketiga tertinggi tempat bersalin (Dinkes Sumsel 2019 dan Riskesdas, 2019).

Persentase cakupan pertolongan persalinan oleh bidan/tenaga kesehatan di fasilitas pelayanan kesehatan di Provinsi Sumatera Selatan adalah 88,4\%. Cakupan pertolongan persalinan di fasilitas kesehatan yang tertinggi terdapat di Kota Prabumulih 100\% dan cakupan terendah terdapat di Kabupaten Muratara 56,2\%. Hal ini berhubungan dengan fasilitas kesehatan yang belum memadai untuk pertolongan persalinan seperti puskesmas dan jaringannya (Dinkes Sumsel, 2019).

Berdasarkan data dari kabupaten Muara Enim yaitupada tahun 2018 persalinan nakes berjumlah 11,555 orang $(89 \%)$, non nakes 1.020 orang (11\%), fasyankes 9,522 orang (82\%) dan non fasyankes 2.057 orang (18\%). Pada tahun 2019 persalinan nakes berjumlah $11.683,1$ orang $(95 \%)$, non nakes 614,9 orang(5\%), fasyankes $11.068,2$ orang $(90 \%)$ dan non fasyankes $1.229,8$ orang $(10 \%)$. Pada tahun 2020 persalinan nakes berjumlah $10.765,84$ orang (92\%), non nakes 936,16 orang (8\%), fasyankes $11.233,92$ orang (96\%) dan non fasyankes 468,08 orang (4\%). Pada bulan Januari - Juni 2021 persalinan nakes berjumlah 5580 orang $(45,98 \%)$, non nakes $25(0.21 \%)$, fasyankes 5319 orang $(43,83 \%)$ dan non fasyankes 261 orang (Dinkes Kab Muara enim, 2021).
Banyak faktor yang melatarbelakangi dalam pemilihan penolong persalinan baik oleh tenaga kesehatan maupun non Nakes antara lain dipengaruhi oleh faktor sosial ekonomi, pendidikan, pengetahuan, sikap, pekerjaan, pendapatan, dukungan keluarga, sosia budaya serta keterjangkauan terhadap pelayanan kesehatan (Amalia, 2012).

Berdasarkan data dari Puskesmas sukarami yaitu pada tahun 2018 persalinan nakes berjumlah 637 orang (89.47\%), non nakes 75 orang $(10.53 \%)$, fasyankes 109 orang $(17.11 \%)$ dan non fasyankes 528 orang $(82.89 \%)$. Pada tahun 2019 persalinan nakes berjumlah 668 orang (93.82\%), non nakes 44 orang $(6.18 \%)$, fasyankes 285orang (42.66\%) dan non fasyankes 383 orang (57.34\%). Pada tahun 2020 persalinan nakes berjumlah 730 orang $(94.93 \%)$, non nakes 39 orang $(5.07 \%)$, fasyankes 382 orang (52.33\%) dan non fasyankes 348 orang (47.67\%). Pada bulan Januari - Juni 2021 persalinan nakes berjumlah 309 orang $(97.48 \%)$, non nakes 8 orang $(2.52 \%)$, fasyankes 194 orang $(62.78 \%)$ dan non fasyankes 115 orang (37.21\%) (Puskesmas Sukarami, 2021).

Penelitian ini bertujuan untuk menidentifikasi hubungan dukungan keluarga, pengetahuan dan sikap ibu dengan kurangnya minat ibu bersalin di fasilitas kesehatan.

\section{METODE}

Penelitian ini adalah penelitian kuantitatif dengan menggunakan survey analitik dengan desain penelitian cross sectional, dimana variabel dependen yaitu Kurangnya Minat Ibu Bersalin di Fasilitas Kesehatan dan variabel independen yaitu pengetahuan, sikap ibu dan dukungan keluarga dikumpulkan secara bersamaan (Notoatmodjo, 2010).

Populasi pada penelitian ini adalah semua ibu bersalin di wilayah kerja Puskesmas Sukarami Kecamatan Sungai Rotan Kabupaten Muara Enim bulan Juli-Agustus Tahun 2021. Tehnik pegambilan sampel yang digunakan dalam penelitian ini adalah non probability sampling berupa accidental sampling, yaitu suatu metode penentuan sampel dengan mengambil responden yang kebetulan ada atau tersedia di suatu tempat sesuai dengan konteks penelitian ( Notoatmodjo ,2010).

Penelitian ini telah memperoleh surat keterangan lolos kaji etik dari Komite Etik Penelitian Kesehtaan Fakultas Kesehatan Universitas Kader Bangsa Palembang dengan No:110/UKB.FKES/TU.KEPK/2021 Pengambilan data dilakukan selama empat minnggu pada bulan Juli-Agustus tahun 2021 dengan menggunakan lembar kuesioner.

\section{HASIL DAN PEMBAHASAN Analisis Univariat}


Delli Aridasari et al., Hubungan Pengetahuan, Sikap Ibu dan Dukungan Keluarga dengan Kurangnya Minat Ibu Bersalin di Fasilitas Kesehatan Wilayah Kerja Puskesmas Sukarami Kecamatan Sungai Rotan Kabupaten Muara Enim

Hasil analisis univariat kurangnya minat bersalin di faskes tergambar pada tabel 1.

Tabel 1. Distribusi Frekuensi dan Persentase Responden Berdasarkan Fasilitas Kesehatan di Wilayah Kerja Puskesmas Sukarami Kecamatan Sungai Rotan Kabupaten Muara Enim

\begin{tabular}{lcc}
\hline Fasilitas Kesehatan & Frekuensi (f) & Persentase (\%) \\
\hline Faskes & 18 & 34,6 \\
Non Faskes & 34 & 65,4 \\
Total & $\mathbf{5 2}$ & $\mathbf{1 0 0}$
\end{tabular}

Sumber data: hasil penelitian

Berdasarkan Tabel 1 diketahu bahwa dari 52 responden, ibu bersalin tidak ke fasilitas kesehatan sebanyak 34 orang $(65,4 \%)$ danibu bersalinke fasilitas kesehatan sebanyak 18 orang $(36,6 \%)$.

Hasil analisis univariat faktor Pengetahuan Ibu tergambar pada tabel 2 .

Tabel 2. Distribusi Frekuensi dan Persentase Responden Berdasarkan Pengetahuan Ibu di Wilayah Kerja Puskesmas Sukarami Kecamatan Sungai Rotan Kabupaten Muara Enim

\begin{tabular}{lcc}
\hline \multicolumn{1}{c}{ Pengetahuan } & Frekuensi (f) & Persentase (\%) \\
\hline Baik & 22 & 42,3 \\
Kurang Baik & 30 & 57,7 \\
Total & $\mathbf{5 2}$ & $\mathbf{1 0 0}$
\end{tabular}

Sumber data: hasil penelitian

Berdasarkan Tabel 2 diketahu bahwa dari 52 responden, ibu berpengetahuan kurang baik sebanyak 30 orang $(57,7 \%)$ sedangkan berpengetahuan baik sebanyak 22 orang $(42,3 \%)$.

Hasil analisis univariat faktor Sikap Ibu tergambar pada tabel 3 .
Tabel 3. Distribusi Frekuensi dan Persentase Responden Berdasarkan Sikap Ibu di Wilayah Kerja Puskesmas Sukarami Kecamatan Sungai Rotan Kabupaten Muara Enim

\begin{tabular}{lcc}
\hline \multicolumn{1}{c}{ Sikap Ibu } & Frekuensi (f) & Persentase $(\%)$ \\
\hline Positif & 20 & 38,5 \\
Negatif & 32 & 61,5 \\
Total & $\mathbf{5 2}$ & $\mathbf{1 0 0}$
\end{tabular}

Sumber data: hasil penelitian

Berdasarkan Tabel 3 diketahu bahwa dari 52 responden, sikap ibu yang negatif sebanyak 32 orang $(61,5 \%)$ sedangkan sikap ibu yang positif sebanyak 20 orang $(38,5 \%)$.

Hasil analisis univariat faktor Dukungan Keluarga tergambar pada tabel 4.

Tabel 4. Distribusi Frekuensi dan Persentase Responden Berdasarkan Dukungan Keluarga di Wilayah Kerja Puskesmas Sukarami Kecamatan Sungai Rotan Kabupaten Muara Enim

\begin{tabular}{lcc}
\hline \multicolumn{1}{c}{ Dukungan Keluarga } & Frekuensi (f) & Persentase (\%) \\
\hline Baik & 37 & 71,2 \\
Kurang Baik & 15 & 28,8 \\
Total & $\mathbf{5 2}$ & $\mathbf{1 0 0}$
\end{tabular}

Sumber data: hasil penelitian

Berdasarkan Tabel 4 diketahu bahwa dari 52 responden, ibu yang mendapatkan dukungan keluarga baik sebanyak 37 orang $(71,2 \%)$ sedangkan responden yang kurang mendapatkan dukungan keluarga sebanyak 15 orang $(28,8 \%)$.

\section{Analisis Bivariat}

Hasil analisis bivariat hubungan Pengetahuan Ibu, sikap ibu dan dukungan keluarga dengan Kurangnya minat bersalin di Fasilitas Kesehatan dapat dilihat pada tabel 5 .

Tabel 5. Hubungan Variabel Independen dan Variabel Dependen

\begin{tabular}{|c|c|c|c|c|c|c|c|c|c|}
\hline \multirow{3}{*}{ No } & \multirow{3}{*}{ Variabel Independen } & \multicolumn{4}{|c|}{ Fasilitas Kesehatan } & \multirow{2}{*}{\multicolumn{2}{|c|}{ Total }} & \multirow{3}{*}{$\begin{array}{c}P \\
\text { Value }\end{array}$} & \multirow{3}{*}{$\begin{array}{c}\text { Odd } \\
\text { Ratio } \\
95 \% \text { CI }\end{array}$} \\
\hline & & \multicolumn{2}{|c|}{ Faskes } & \multicolumn{2}{|c|}{ Non Faskes } & & & & \\
\hline & & $\mathbf{n}$ & $\%$ & $\mathbf{n}$ & $\%$ & $\mathbf{N}$ & $\%$ & & \\
\hline \multirow[t]{3}{*}{1} & Pengetahuan & & & & & & & & \\
\hline & 1. Baik & 12 & 54,5 & 10 & 45,5 & 22 & 100 & $\mathbf{0 , 0 2 2}$ & 4.800 \\
\hline & 2. Kurang Baik & 6 & 20,0 & 24 & 80,0 & 30 & 100 & & \\
\hline \multirow[t]{3}{*}{2} & Sikap Ibu & & & & & & & & \\
\hline & 1. Positif & 11 & 55,0 & 9 & 45,0 & 22 & 100 & $\mathbf{0 , 0 3 2}$ & 4.365 \\
\hline & 2. Negatif & 7 & 21,9 & 25 & 78,1 & 32 & 100 & & \\
\hline \multirow[t]{3}{*}{3} & Dukungan Keluarga & & & & & & & & \\
\hline & 1. Baik & 17 & 45,9 & 20 & 54,1 & 37 & 100 & 0,018 & 11.900 \\
\hline & 2. Kurang Baik & 1 & 6,7 & 14 & 93,3 & 15 & 100 & & \\
\hline
\end{tabular}

Sumber data: hasil penelitian

Berdasarkan tabel 5 hasil analisis hubungan pengetahuan dengan kurangnya minta bersalin di faskes diperoleh bahwa ibu berpengetahuan baik yang bersalin ke fasilitas kesehatan sebanyak 12 orang (54,5\%), Sedangkan ibu yang berpengetahuan kurang baik bersalin ke fasilitas kesehatan sebanyak 6 orang $(20,0 \%)$. Hasil uji statistik diperoleh nilai $p$ value $=0,022 \leq \alpha=$ 0,05 maka dapat disimpulkan bahwa ada hubungan yang signifikan pengetahuan ibu dengan kurangnya minat bersalin difasilitas kesehatan di Wilayah Kerja 
Delli Aridasari et al., Hubungan Pengetahuan, Sikap Ibu dan Dukungan Keluarga dengan Kurangnya Minat Ibu Bersalin di Fasilitas Kesehatan Wilayah Kerja Puskesmas Sukarami Kecamatan Sungai Rotan Kabupaten Muara Enim

Puskesmas Sukarami Muara Enim tahun 2021. Hasil analisis diperoleh nilai OR : 4.800 artinya ibu yang berpengetahuan baik berpeluang 4,800 kali untuk bersalin ke fasilitas kesehatan dibandingkan dengan ibu berpengetahuan kurang baik.

Hasil Penelitian ini sejalan dengan penelitian Kamila dan Rahmasari (2020), bahwa menunjukkan ibu yang memilih tempat persalinan difaskes lebih banyak ditemukan pada ibu yang berpengetahuan baik sebanyak 16 orang $(69,6 \%)$ dan ibu yang memilih tempat persalinan non faskes lebih banyak ditemukan pada ibu yang berpengetahuan cukup dan kurang sebanyak 3 orang $(42,9 \%)$. Jadi dapat disimpulkan bahwa dari tingkat pengetahuan yang dimiliki, ibu cenderung memilih tempat persalinan difaskes. Hasil analisis uji statistik dengan menggunakan chi square diperoleh nilai $\mathrm{p}=0,034<0,05$ artinya Ho ditolak dan Ha diterima sehingga dapat disimpulkan bahwa ada hubungan antara pengetahuan ibu tentang tanda-tanda bahaya persalinan dengan pemilihan tempat persalinan.

Pengetahuan baik seseorang tentang kesehatan reproduksi terutama resiko penolong persalinan oleh tenaga non nakes, maka mereka bisa mengambil keputusan yang baik tentang kesiapan untuk bersalin, Seseorang yang memiliki pengetahuan yang rendah tentang resiko yang dapat timbul pada persalinan, maka akan menganggap bahwa tenaga penolong persalinan/fasilitas kesehatan bisa oleh siapa saja selain tenaga nakes (Soetijiningsih, 2012).

Menurut asumsi peneliti mayoritas pengetahuan ibu tentang tempat persalinan masih kurang karena hal ini mempengaruhi cara pandang seseorang yang pemahamannya berbeda-beda tentang persalinan yang aman, bersih dilakukan, hal ini kurangnya informasi yang ibu-ibu dapatkan membuat rasa ingin tahu resiko atau komplikasi tentang persalinan dirumah yang tidak terduga dan jika tidak ditolong oleh petugas kesehatan. Oleh karena itu sosialisasi dari petugas kesehatan sangat penting dilaksanakan disetiap daerah agar ibu-ibu yang memilih tempat bersalin dapat memberikan pemahaman, pengertian dan pengetahuan seorang ibu.

Hasil analisis hubungan sikap ibu dengan kurangnya minta bersalin di faskes diperoleh bahwa sikap ibu yang positif ada 11 orang $(55,0 \%)$ yang bersalin difaskes, sedangkan sikap ibu yang negatif ada 7 orang $(21,9 \%)$ yang bersalin difaskes. Hasil uji statistik chi square diperoleh nilai $p$ value $=0,032 \leq \alpha=$ 0,05 , maka dapat disimpulkan bahwa ada hubungan yang signifikan antara sikap ibu dengan kurangnya minat ibu bersalin difasilitas kesehatan.Hasil analisis diperoleh nilai OR : 4.365 artinya sikap ibu bersalin yang positif berpeluang 4,365 kali untuk bersalin ke fasilitas kesehatan dibandingkan sikap ibu yang negatif.

Hasil penelitian sejalan dengan penelitian Adriana (2014) dengan judul Akses Pelayanan Kesehatan Berhubungan dengan Pemanfaatan Fasilitas Persalinan yang Memadai di Puskesmas Kawangu, Kabupaten
Sumba Timur.untuk variabel sikap mendapatkan hasil pvalue 0,001 artinya ada hubungan yang kuat antara sikap ibu dengan pemilihan fasilitas kesehatan sebagai tempat persalinan.

Sikap seseorang berpengaruh dalam prilaku seseorang dalam bertindak khusunya dalam bidang kesehatan. Sikap ibu bersalin mempengaruhi pemilihan tenaga penolong persalinan atau tempat persalinan. Sikap yang positif terhadap tenaga penolong persalinan akan membuat ibu memilih tenaga nakes/fasilitas kesehatan dalam membantu proses persalinan. Menurut Azwar (2011).

Menurut asumsi peneliti bahwa responden yang bersikap positif mayoritas ibunya melahirkan di fasilitas kesehatan karena ibunya mempunyai pengetahuan yang baik sehingga menghasilkan tindakan yang positif dalam perilaku kesehatan, tetapi dari responden bersikap negatif tidak melahirkan di fasilitas kesehatan dikarenakan ibu kurang memahami pentingnya kesehatan ibu dan anak setelah persalinan.

Hasil analisis hubungan dukungan keluarga dengan kurangnya minta bersalin di faskes diperoleh bahwa ibu yang mendapatkan dukungan dari kelurga ada 17 orang $(45,9 \%)$ bersalin di faskes, sedangkan dari 15 responden yang kurang mendapatkan dukungan dari keluarga yang bersalin ke fasilitas kesehatan sebanyak 1 orang $(6,7 \%)$. Hasil uji statistik chi square diperoleh nilai $p$ value $=0,018 \leq \alpha=0,05$, maka dapat disimpulkan bahwa ada hubungan yang signifikan antara dukungan keluarga dengan kurangnya minat bersalin difasilitas kesehatan. Hasil analisis diperoleh nilai OR : 11,900 artinya responden yang mendapatkan dukungan keluarga berpeluang 11.900 kali untuk bersalin ke fasilitas kesehatan dibandingkan dengan ibu yang kurang mendapat dukungan keluarga.

Hasil penelitian ini sejalan dengan penelitian Ulfah (2017) dengan judul faktor-faktor yang berhubungan dengan pemilihan tempat bersalin bahwa ada hubungan antara dukungan keluarga dengan pemilihan tempat bersalin yaitu nilai p.value 0,000 .

Dukungan atau motivasi adalah sesuatu hal yang menyebabkan dan yang mendukung tindakan atau perilaku seseorang. Dukungan mengacu pada dorongan dan usaha untuk memuaskan kebutuhan atau suatu tujuan.Dukungan menjadi suatu alasan seseorang untuk bertindak dalam rangka memenuhi kebutuhan hidupnya (Notoatmodjo, 2010).

Menurut Asumsi peneliti dukungan keluarga dapat mempengaruhi dalam pemilihan tempat persalinan karena keluarga kurang mampu lebih cenderung memilih rumah sebagai tempat persalinan daripada di fasilitas kesehatan karena ekonomis keluarga yang kurang mampu.Khusus pedesaan keluarga kurang mampu yang memanfaatkan rumah sebagai tempat persalinan semakin besar. Hal ini di sebabkan keluarga merasa lebih nyaman di rumah dikarenakan lebih banyak yang menunggu ibu bersalin dan lebih murah biaya persalinannya. 
Delli Aridasari et al., Hubungan Pengetahuan, Sikap Ibu dan Dukungan Keluarga dengan Kurangnya Minat Ibu Bersalin di Fasilitas Kesehatan Wilayah Kerja Puskesmas Sukarami Kecamatan Sungai Rotan Kabupaten Muara Enim

\section{SIMPULAN}

Hasil analisis menunjukkan bahwa pengetahuan ibu (p.value 0,022), sikap ibu (p.value 0,032) dan dukungan keluarga (p.value 0,018) memiliki hubungan signifikan dengan kurangnya minat ibu bersalin di faskes wilayah kerja Puskesmas Sukarami Kab. Muara Enim hasil analisis diperoleh nilai OR : 4.800 dimana ibu berpengetahuan baik berpeluang 4.800 kali bersalin di faskes dibandingan ibu berpengetahuan kurang baik, Hasil analisis diperoleh nilai OR : 4.365 artinya sikap ibu bersalin yang positif berpeluang 4,365 kali untuk bersalin ke fasilitas kesehatan dibandingkan sikap ibu yang negatif dan variabel dukungan keluarga diperoleh nilai OR : 11,900 artinya responden yang mendapatkan dukungan keluarga berpeluang 11.900 kali untuk bersalin ke fasilitas kesehatan dibandingkan dengan ibu yang kurang mendapat dukungan keluarga.

\section{DAFTAR PUSTAKA}

Adriana, Nara. 2014. Akses Pelayanan Kesehatan Berhubungan dengan Pemanfaatan Fasilitas Persalinan yang Memadai di Puskesmas Kawangu, Kabupaten Sumba Timur. https://repositori.unud.ac.id/protected/storage/uplo ad/repositori/a0b123bce9d128029196b0f0e45202 68.pdf. Diakses 21 Agustus 2021

Amalia.2012.faktor-faktor yang mempengaruhi dalam pemilihan penolong persalinan diwilayah kerja Puskesemas Molopatodu Kecamatan Bongomeme Kabupaten Gorontalo. https://ejurnal.ung.ac.id/index.php/ST/article/view 11128. Diakses 18 Agustus 2021

Azwar, S. 2013. Sikap dan Perilaku dalam Sikap Manusia Teori dan Pengukurannya. Yoyakarta: Pustaka Belajar

Dinkes Kota Palembang. 2020. Profil Dinkes Kota Palembang. 2019

Dinkes Provinsi Sumsel. 2020. Profil Dinkes Sumatera Selatan. 2019

Dinkes Kab. Muara Enim. 2020. Profil Dinkes Kabupaten Muara Enim. 2019

Kamiladan Rahmasari. 2020. Hubungan pengetahuani butentang tanda-tanda bahaya persalinan dengan pemilihan tempat persalinan diwilayah kerja Puskesmas Lendang Nangka-Lombok Timur tahun 2020.

http://ejournal.unwmataram.ac.id/jikf/article/view/ 529. Diakses 20 Agustus 2021.

Kementerian RI, 2019. Profil Kesehatan Indonesia Tahun 2019. Kementrian Kesehatan RI Jakarta.

Notoatmodjo, S. 2010. Metodologi Riset Keehatan. Jakarta: Rineka Cipta

Puskesmas Sukarami. 2021. Profil Puskesmas Sukaram Muara Enim. 2020

Riskesdas. 2019. Riset Kesehatan Dasar Nasional. 2020

SDKI, 2017. Survey Demografi Kesehatan Indonesia.
Soetijiningsih, 2012. Perkembangan Anak dan Permasalahannya dalam Buku Ajar Ilmu Perkembangan Anak dan Remaja. Jakarta: Sangungseto

Ulfah.2017.faktor-faktor yang berhubungan dengan pemilihan tempat bersalin. http://jurnal.umb.ac.id/index.php/keperawatan/arti cle/view/716. Diakses 21 Agustus 2021 